\title{
MARGARET MCDONALD STANTON
}

BY MRS. DORA SAYLES OSBORN.

FrRst on the roll of honor of the State should be placed the names of its successful teachers, those who have given to its youth, its future citizens, not only the material elements of an education, but also those high ideals of life, those lofty ambitions which are of inestimable value in the formation of character.

The trustees of the Iowa Agricultural College were peculiarly fortunate in the selection of the first faculty. President A. S. Welch, of revered memory', who gave the best years of his life to laying broad and deep the foundations of the institution which is now a lasting monument to his wise forethought; Dr. W. H. Wynn, still an honored member of its working force; Dr. C. E. Bessey, of national reputation as a scientist, and others, who in various ways left a lasting impress on its future.

Of them all, and, indeed, of all who have come and gone in the twenty-five years following, not one has been more closely or honorably identified with the history of the college than the late Mrs. Margaret M. Stanton, who came in the flush of young womanhood, as a member of this first faculty, being preceptress and teacher of French and English.

Margaret McDonald was born in New Concord, Muskingum county, Ohio, October 22, 1845, and died at her home at the Iowa Agricultural College, Ames, Iowa, July 25, 1895. Eighteen years of her life were spent in her native State at a time of great national peril, and in a region where feeling on the slavery question ran high. Her naturally strong character was deeply influenced by the stirring events of the time, her innate sense of justice being 


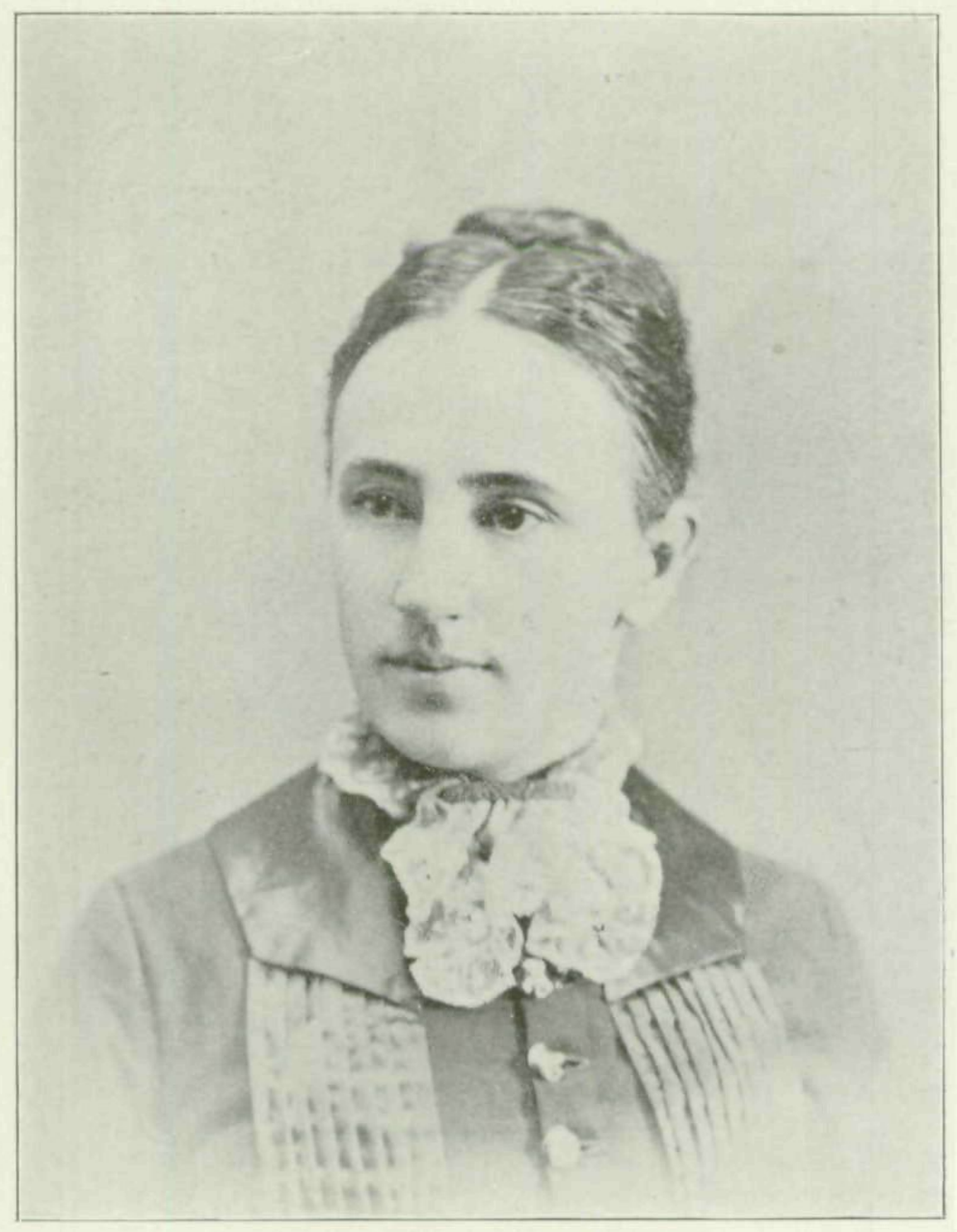

Mrs. Margant M. Stautou. THE LATE MKS. MARGARET M. STANTON, Of Iowa Agricultural College. 
crystallized into a life-long hatred of injustice or oppression in any form, and her thoughtful mind filled with a love for humanity and a lasting trust in the God of Nations.

After leaving the public schools she spent three years in Muskingum College; but, the family home being transferred to Mt. Pleasant, Iowa, her collegiate education was completed at Mt. Pleasant Seminary, where she graduated with honor, having been in study as in everything else, ambitious and thorough.

Her career as a teacher began in the public schools and she spent her vacations in an educated French family, diligently pursuing the study of their language. In 1871 she was elected to the chair which she so ably filled in the Agricultural College. These were pioneer days in the college, and added to the usual trials incident to the establishment of such an enterprise were those which arose from the fact that industrial education, and co-education in great institutions, were both in the experimental stage. How much the counsel of a noble, unselfish, brave and tactful woman was worth in those first trying days, it would be impossible to tell. Dr. Wynn her associate, says of her at that time: "When I first entered upon my work here, I found her department lying closely contiguous to my own, and had frequent occasion to carry my perplexities, and plans, and class-room complications to her, and I never found her judgment at fault. Her intuitions were quick and unerring, and with a slight hesitancy of speech, which we all tenderly remember, she always sought out the best advice in the best words. Who ever knew her to go wrong or lose her womanly equipoise, or let her feelings, often visibly disturbed, run into the railing of anger, or the bitterness of spite? We seem now to see her all along those years, a model woman, to whom young men and women brought the story of their trials, and from whose presence they never went away unprofited, and back to whom, in any time of difficulty and distress, they were 
always glad to resort. Pre-eminently did these transcendent traits of character appear, when she moved among the faculty, and addressed herself to her share of responsibility, grave and heavy at all times, in the management of this great college; and there was no part of the difficult regime with which she might not have been trusted."

It is certainly largely due to her wise management that co-education was here successful, that the college has always had a goodly proportion of young women among its students, and that the fields of higher education are here open to them on the same basis as to men.

Though always very successful in class-room work, her greatest influence lay in her social relations with the students. She impressed her personality upon them to a remarkable degree, so that they remember her as an ideal character more than for the innumerable kind acts which marked her career among them. In testimony of this, letters came to her bereaved husband from far and near, uniformly expressing an appreciation of the lasting influence she had exerted on the lives of the writers. They call her "a model woman"-_" an ideal character"- "an example to be emulated"- "a mother to hundreds of students" - "one of the agencies by which Dr. Welch sought to build character in young people"-_"a devout Christian whose life exemplified the great truths of the Christian religion."

Not only mindful of the larger and more public duties, she never forgot the little courtesies which make life sweet. Burdened with an unusual responsibility for one so young, her helpful care over the parental home was never lessened. The struggles of the good parents to establish a new home in a new state, were lightened by generous aid and loving interest, while the education and encouragement of the younger children was to her a sacred duty. After her marriage to Prof. E. W. Stanton, which occurred February 22, 1877, she continued her college work 
for two years, when she voluntarily resigned in order to establish a home; but her interest and influence continued, while her home became not only a hallowed spot to its inmates but a power and a blessing in the community. It was a Mecca to the old student revisiting Alma Mater toward which his footsteps always turned, and where he found an abiding interest and affection most grateful amid the constantly changing scenes of college life.

That this feeling was shared by those who came to know her in later years is beautifully shown by the tribute from Dr. Beardshear, in his address at the memorial exercises: "Home life is capable of infinite expansion and variation. It nourishes and yet reveals life and character. The cardinal virtues that had made her so much in the profession of teaching, now had a larger realm for her as wife and mother. The years of her married life gained double meaning by the birth of four children, three of whom live with the father on earth and one with the mother in Heaven. She brought to the home an intuition which was almost unerring. To woman's proverbial intuition, she had an added gift that made her judgment of men and things of vast practical value to herself and family. Coupled with it was an independence of thought and decision of character that made her a tower of strength to all the members of the family and to the community. Her love and devotion to the family were most beautiful. Her thought was always of others and not of herself. Her clearness and firmness of judgment freed her of many cares and worries that so often fret the life and tire the soul. Her patience and endurance surpassed every demand and rendered her a fountain of never-failing strength and cheer. It kept out impatient words and brought whole trains of happy scenes and joyful hours. Her entire home life was most happy and markedly free from anything that would mar or sadden. She believed with Ruskin, that-'Our God is a household God, as well as a 
heavenly one; he has an altar in every man's dwelling,' and to this altar she daily led her household and at this altar gave them her final good-byes and consecrations for the years to come. She was a noble wife and the truest of mothers."

The beautiful Woman's Building which was first occupied a week before her death has been named "Margaret Hall" in honor of her, and in her memory her husband has presented to the college a magnificent chime of bells whose silver tones will hourly speak to future generations, in a harmony symbolizing that to which her life was tuned.

THE emigration to Iowa the present season will far exceed that of any former year since our rich bottom lands and wide spread prairies were first thrown open to settlement. Every road leading into the great valley of the Des Moines is blocked up with emigrant wagons, herds of moving stock, etc., slowly but surely wending their way to a home in this desirable country. Let them come, there is room, and to spare. Thousands of acres of as good and well situated land as the sun ever shone on, yet lie vacant in the new counties of the Des Moines Valley, which can be taken up, at $\$ 1.25$ per acre. The climate is mild and healthy, and it embraces as many if not more natural advantages than any country in the west. All that Iowa requires to make her one of the first States in the Union, is the early development of her giant resources. Strong arms and resolute hearts can do this. All such are welcome to our midst.-Ottumwa Courier, November 2, 1849. 
Copyright of Annals of Iowa is the property of State of Iowa, by \& through the State Historical Society of Iowa and its content may not be copied or emailed to multiple sites or posted to a listserv without the copyright holder's express written permission. However, users may print, download, or email articles for individual use. 